\title{
Pemanfaatan Ampas Tebu Sebagai Pembangkit Listrik Biomassa Di PG. Sragi Pekalongan
}

\author{
M. Chaerul Amin ${ }^{1}$, Arif Johar Taufiq ${ }^{2}$, Itmi Hidayat Kurniawan ${ }^{3}$
}

Program Studi S1 Teknik Elektro, Universitas Muhammadiyah Purwokerto Fakultas Teknik dan Sains, Universitas Muhammadiyah Purwokerto

\section{Informasi Makalah}

Dikirim, 8 Mei 2019

Direvisi, 1Juli 2019

Diterima,

\section{Kata Kunci:}

Tebu

Ampas tebu

Homer energy

\section{INTISARI}

Seiring perkembangan zaman, dunia kini menuntut terpenuhinya aspek kecepatan, ketepatan, dan efisiensi sehingga semua pihak dituntut untuk terus menghasilkan inovasi terbaru dengan teknologi mutakhir yang akan mengarah pada peningkatan permintaan energi listrik. Namun masalah utamanya adalah dalam bisnis penyediaan energi listrik yang masih sangat bergantung pada bahan bakar fosil, yang semakin menipis. Dengan kondisi ini, pengadaan energi alternatif dan terbarukan baru, efisien dan ramah lingkungan sangat diperlukan. Misalnya adalah ampas tebu. Hingga saat ini, ampas tebu hanya digunakan sebagai pakan ternak atau bahan pupuk dan pembuatan batu bata. Namun, dengan semakin berkembangnya areal perkebunan tebu dan didukung oleh penelitian tentang kandungan kalori ampas tebu, maka penggunaan ampas tebu sebagai bahan bakar dimulai. Setiap kilogram ampas tebu dengan kadar gula sekitar 2,5\% memiliki panas 1825 kkal. Pada penelitian ini, dilakukan audit energi dan pengamatan tentang penggunaan ampas tebu sebagai bahan bakar pembangkitan listrik di Pabrik Gula Sragi Pekalongan menggunakan aplikasi Homer. Hasil penelitian menunjukan potensi ampas tebu 14,363 ton/jam secara teori yang sudah dikonversikan menjadi energi listrik sebesar 30,48 MW dengan nilai kalori 26.214.300 kkalori. Pada hasil simulasi menggunakan software homer energy mendapatkan nilai ampas tebu pertahunnya pada saat musim giling sebesar 5.725 ton/tahun dan telah dikonversikan menjadi energi listrik sebesar $2.204 .100 \mathrm{kWh} /$ tahun dengan penerapannya menggunakan generator 2 MW.

\begin{abstract}
Along with the times, the world is now demanding the fulfillment of the aspect of speed, accuracy, and efficiency so that all parties are required to continue to produce the latest innovations with cutting-edge technology that will lead to increased demand for electrical energy. But the main problem is in the business of providing electrical energy are still highly dependent on fossil fuels, which are dwindling. With this condition, the procurement of new alternative and renewable energies, efficient and environmentally friendly is indispensable. For example is bagasse biomass. Until now, the bagasse is only used as fodder or ingredient in fertilizer and the manufacture of bricks. However, with the increasing development of sugar cane plantation area and supported by research on the content of the calorific of the bagasse, then the use of bagasse as fuel started. Each kilogram of bagasse with sugar content about $2.5 \%$ has a heat of $1825 \mathrm{kcal}$. In this thesis, energy audit and observations about the use of bagasse as fuel for electricity generation conducted at sugar factory Sragi Pekalongan with method analys Homer energy. The results of this thesis research potential of bagasse 14,363 tons
\end{abstract}

/ hour in theory which has been converted into electrical energy of 30.48 MW with a calorific value of $26,214,300$ kcalories. in the simulation results using homer energy software get the bagasse value annually during the milling season of 5,725 tons / year and has been converted into electrical energy of 2,204,100 kWh / year by applying it using a 2 MW generator. 


\section{Korespondensi Penulis: \\ M. Chaerul Amin \\ Program Studi S1 Teknik Elektro \\ Universitas Muhammadiyah Purwokerto \\ Jl. Raya Dukuh Waluh Purwokerto, 53182 \\ Email: mchaerulamien@gmail.com}

\section{PENDAHULUAN}

Biomassa merupakan material yang berasal dari makhluk hidup. Dalam kaitannya dengan energi biasanya berasal terutama dari tumbuh tumbuhan seperti kayu, potongan dedaunan dan ranting, serta rumputrumputan. Di samping itu, biji- bijian yang mengandung minyak seperti sawit dan kelapa juga termasuk dalam kategori biomassa ini. Selain itu, kotoran hewan pun sering dikategorikan sebagai salah satu biomassa ini. Material biomassa mulai banyak dipergunakan sebagai sumber energi yang lebih ramah lingkungan. Besarnya potensi biomassa dapat dijadikan energi alternatif pilihan yang mudah didapat serta ramah lingkungan. Sebagai contoh pemanfaatan biomassa antara lain limbah kelapa sawit dan ampas tebu yang dimanfaatkan sebagai bahan bakar pembangkit listrik untuk perusahaan. Dari penelitian sebelumnya yang telah dilakukan di Pabrik Gula Pangkah Tegal memiliki potensi dari ampas tebu sebanyak 403,365 ton/hari sampai 422,945 ton/hari pada tahun 2017. Proses giling di PG. Pangkah Tegal bulan Juni - November namun tidak sampai akhir bulan. Saat proses giling menghasilkan daya sebesar 1.131,25 kW dan saat PG. Pangkah tidak produksi mendapat asumsi dari PLN sebesar 38,250 kW di bulan Desember - Mei 2017 (Tiyas, 2017).

Indonesia memiliki banyak pabrik gula yang tersebar dihampir setiap wilayah. Pabrik-pabrik gula tersebut menghasilkan limbah tebu sisa produksi yang cukup banyak untuk dimanfaatkan. Limbah ampas tebu di Pabrik Gula merupakan salah satu biomassa yang perlu dianalisis potensinya dan dikembangkan. Pada pabrik gula memanfaatkan ampas tebu digunakan untuk pembakaran boiler agar memperoleh uap.

\section{METODE PENELITIAN}

\subsection{Analisis Situasi}

Tahap awal dalam metodelogi penulisan ini. Pada tahap ini dilakukan studi lapangan dengan mengamati langsung keadaan gedung dan beban yang terpasang di Pabrik Gula Sragi Pekalongan .

\subsection{Identifikasi Perumusan Masalah}

Dalam penelitian ini, permasalahan yang diangkat menjadi topik bahasan adalah tentang studi pemanfaatan limbah tebu sebagai pembangkit listrik biomassa yang merupakan energi terbarukan ramah lingkungan. Disamping itu, limbah tebu dapat menghasilkan energi alternatif berupa gas biomassa yang jika diproses lebih lanjut dapat menghasilkan gas hidrogen sebagai bahan bakar gas dan bahan bakar cair berupa metanol ataupun etanol. Sementara itu limbah atau sisanya dapat dimanfaatkan lagi sebagai bahan pupuk bagi pertanian.

\subsection{Studi Pustaka}

Studi pustaka yang dilakukan dengan mencari informasi dan referensi dalam bentuk buku, jurnal, informasi, dari internet maupun sumber-sumber lainnya seperti diskusi bersama dosen.

\subsection{Pengumpulan Data}

Pengumpulan data pada penelitian ini diperoleh dari hasil wawancara dengan pengelola Pabrik Gula Sragi Pekalongan, data perusahaan yang sudah ada, serta dari literatur yang berhubungan dengan pengumbulan data yang dibutuhkan selama proses penelitian

\subsection{Pengolahan Data}

Pengolahan data dilakukan dengan menghitung secara ilmiah dan menggunakan Software Homer Energy untuk mengetahui potensi biogas yang dapat dihasilkan dari limbah ampas tebu di Pabrik Gula Sragi Pekalongan menjadi energi listrik. 


\subsection{Analisis Data}

Data yang dianalisis adalah potensi dari limbah tebu pabrik gula serta data beban yang diperoleh dari Pabrik Gula Sragi Pekalongan. Pada tahap menghitung secara teori akan mendapat hasil dari data ampas tebu PG. Sragi menjadi energy listrik, biaya pembangkitan, biaya pembangunan, jumlah pembangkitan energy listrik, biaya bahan bakar, biaya operasi dan perawatan dan biaya pembangkitan total untuk dibandingkan dengan keadaan di PG. Sragi Pekalongan setelah sudah melakukan analisis secara manual tahap selanjutnya Software Homer Energy akan menentukan konfigurasi terbaik dalam sistem dan kemudian memperkirakan biaya instalasi dan operasi sistem selama masa operasinya (life time cost).

\section{HASIL DAN PEMBAHASAN}

\subsection{Konsumsi Daya Listrik}

Sumber kelistrikan di Pabrik Gula Sragi berasal dari suplai listrik PLN dan dibantu dengan sistem pembangkit listrik yang mampu menopang total beban keseluruhan industri. Sistem pembangkit tersebut menggunakan generator dengan daya $2.000 \mathrm{~kW}$. Pabrik Gula Sragi berproduksi selama 24 jam disaat musim giling yaitu pada bulan Mei sampai September Tahun 2018. Pada saat pabrik tidak berproduksi Pabrik Gula Sragi mendapat suplai listrik dari PLN sebesar $360 \mathrm{~kW}$.

\subsection{Potensi Feedstock Biomassa}

Grafik rata-rata biomassa dalam setahun dapat dilihat pada gambar 3.1 di bawah ini dengan menggunakan aplikasi Homer Energy.

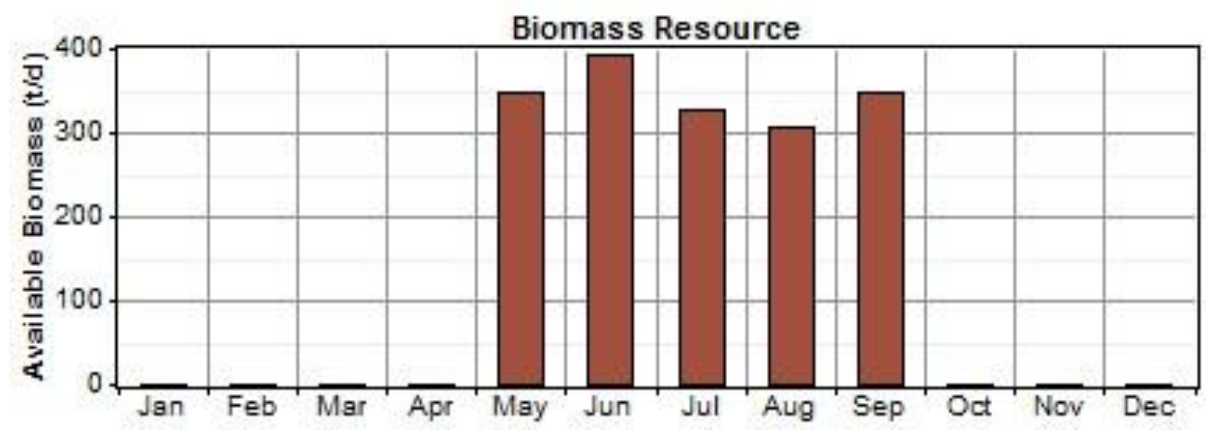

Gambar 3.1 Grafik Feedstock 


\subsection{Analisis Perhitungan Secara Teori PG. Sragi Pekalongan}

Dibawah ini adalah tabel data yang dapatkan selama musim giling Bulan Mei sampai dengan September Tahun 2018:

Tabel 3.1 Kapasitas Giling PG. Sragi

\begin{tabular}{lcccccc}
\hline No & $\begin{array}{c}\text { Musim } \\
\text { giling } \\
\text { (Bulan) }\end{array}$ & $\begin{array}{c}\text { Tebu Giling } \\
\text { Per Hari } \\
\text { (kuintal) }\end{array}$ & $\begin{array}{c}\text { Tebu Giling } \\
\text { Per Jam } \\
\text { (kuintal) }\end{array}$ & $\begin{array}{c}\text { Ampas } \\
\text { Masuk } \\
\text { (ton) }\end{array}$ & $\begin{array}{c}\text { Ampas } \\
\text { Sisa } \\
\text { (ton) }\end{array}$ & Operasi \\
\hline 1 & Mei & $19.379,47$ & 807,47 & 14,54 & 9,68 & 6 \\
2 & Juni & $27.238,69$ & $1.134,95$ & 16,35 & 17,69 & 21 \\
3 & Juli & $20.238,6$ & 843,275 & 13,65 & 11,64 & 30 \\
4 & Agustus & $21.418,44$ & 892,43 & 12,74 & 14,03 & 31 \\
5 & September & $20.130,31$ & 838,76 & 14,54 & 10,62 & 16 \\
\hline
\end{tabular}

Berdasarkan dari tabel 3.1 ampas yang masuk ke boiler rata-rata sebesar 14,364 ton/jam atau setara dengan energy listrik sebesar $1.825 \mathrm{kcal} / \mathrm{kg}$ maka dari rata-rata perjam ampas tebu yaitu sebesar 26.214.300 $\mathrm{kcal} / \mathrm{kg}$. Rata-Rata ampas tebu yang dipakai untuk menghasilkan daya tersebut sebanyak 344,736 ton ampas tebu/hari atau 14,364 ton/jam. Sehingga, 14,364 ton ampas tebu x $1.000=14.364 .000 \times 1.825=26.214 .300$ kcalori / 860 (nilai konversi energi listrik biomassa) $=30.481,7 \mathrm{~kW}=30,48 \mathrm{MW} / \mathrm{Jam}=3.169,92$ MW/Tahun.

Padahal, dalam kenyataannya, daya listrik yang dihasilkan maksimal hanya 2 MW. Perbedaan yang sangat besar antara energi ideal yang terkandung dalam ampas tebu dan energi yang dihasilkan di lapangan karena pembangkit ini memiliki efisien yang sangat rendah. Sehingga ada cukup banyak energi yang tidak terkonversi menjadi listrik. Berdasarkan perhitungan dan data tersebut dapat kita hitung efisiensi dari pembangkit listrik tenaga uap ini.

$$
\eta=\frac{\text { energi listrik yang dihasilkan }}{\text { energi yang terkandung }} \times 100=\frac{2}{30,48} \times 100 \%=6,5 \%
$$

Menurut perhitungan, dalam 1 hari akan dihasilkan ampas tebu sisa sebanyak 63.66 ton ampas tebu sisa/hari. Hal itu setara dengan energi listrik sebesar 135,09 MW/Hari. Bila dalam 1 hari, rata-rata ampas tebu sisa yang dihasilkan selama 5 bulan ini sebanyak $12.732 \mathrm{~kg} / \mathrm{jam}$. Maka bila ampas tebu tersebut digunakan untuk tambahan bahan bakar pada pembangkitan ini, akan kembali dihasilkan energi listrik sebesar : $=12.732 \mathrm{~kg} x 1825 \mathrm{kcal} \times 6,5 \%=1.742 .692,5 \mathrm{kcal}=2,02 \mathrm{MW}$

Namun, kelemahan dari PLTU bahan bakar ampas tebu ini adalah listrik hanya bisa dihasilkan pada waktu musim giling. sedangkan musim giling pada PG. Sragi selama 104 hari. Sehingga listrik yang dapat disalurkan ke PLN juga maksimal selama 104 hari saja. 


\subsection{Analisis Peracangan Pembangkit Listrik Biomassa Software Homer Energy}

Pada perancangan sistem pembangkit listrik energi biomassa ini Homer Energy akan menganalisis rancangan yang terhubung ke grid PLN. Gambar 3.2 menunjukkan tampilan komponen Homer yang tersedia. Pada perancangan sistem ini, komponen yang dipakai Generator 1 yang selanjutnya diatur bahan bakarnya menggunakan biomassa dan beban yang dipilih adalah Primary Load

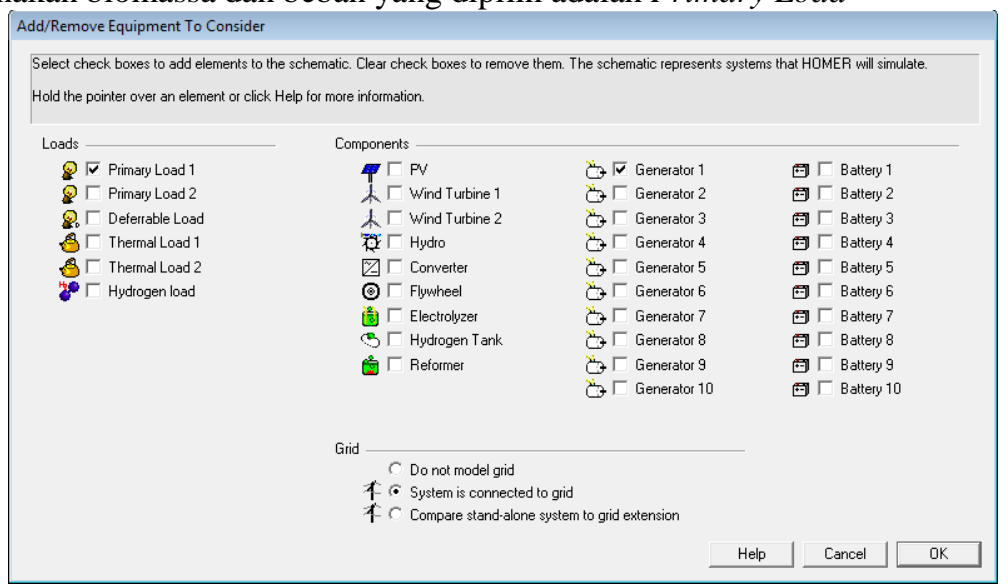

Gambar 3.2 Pemilihan Komponen pada Software Homer Energy

\section{a. Simulasi Primary Load}

Simulasi Primary Load merupakan simulasi beban kelistrikan, dalam penelitian Skripsi ini adalah beban kelistrikan Pabrik Gula Sragi. Data kelistrikan Pabrik Gula Sragi yang telah didapat dimasukkan ke dalam system perancangan.

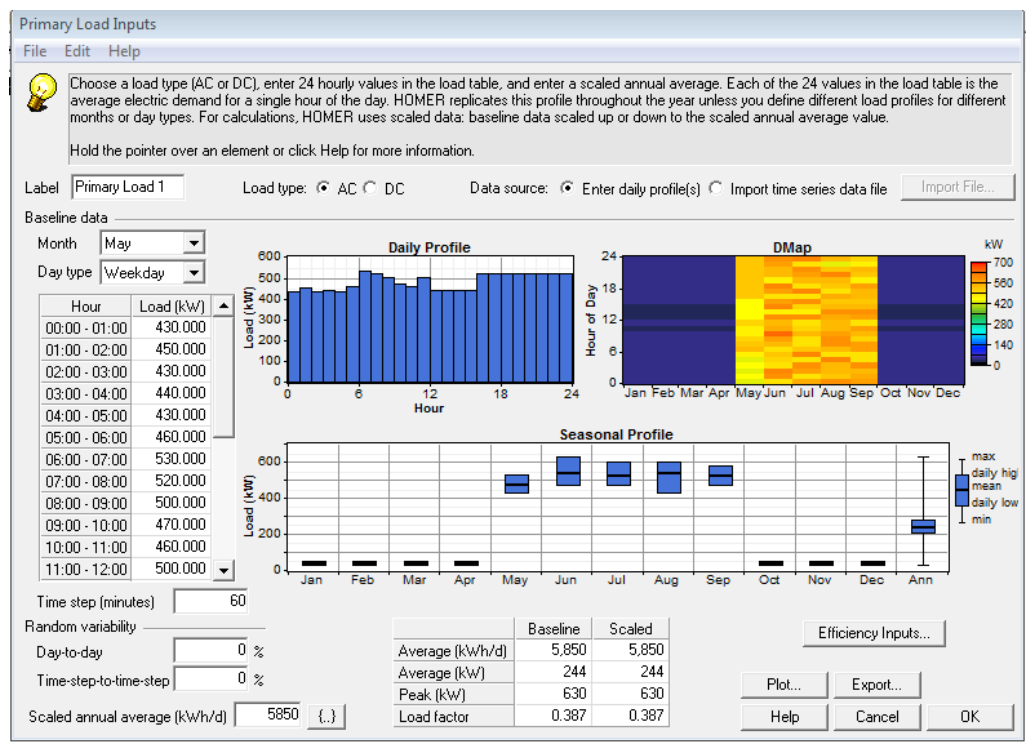

Gambar 3.3 Perancangan Load Bulan Mei s/d September 2018 
Pada gambar 3.3 di atas menunjukkan hasil simulasi pada bulan Mei sampai bulan September. pada bulan tersebut musim giling Pabrik Gula Sragi atau dengan kata lain sedang berproduksi sehingga daya yang terpakai untuk beban terbilang besar. Jadi pada bulan Mei sampai September diasumsikan beban industri rata-rata adalah $481,5 \mathrm{~kW}$.

Sedangkan untuk hasil simulasi pada bulan Oktober sampai bulan April di tunjukkan oleh gambar 3.4 berikut. Dimana pada bulan tersebut merupakan tidak musim giling Pabrik Gula Sragi atau dengan kata lain sedang pabrik tidak berproduksi sehingga daya yang terpakai untuk beban kecil sebesar 41,375. Sehingga Homer dapat mengakomodasi perubahan profil beban listrik untuk setiap bulannya. Namun, pada penelitian ini profil beban listrik untuk daerah tropis dapat dianggap sama untuk setiap bulannya. Hal ini disebabkan karena tidak adanya perbedaan iklim yang sangat mencolok dalam periode satu tahun.

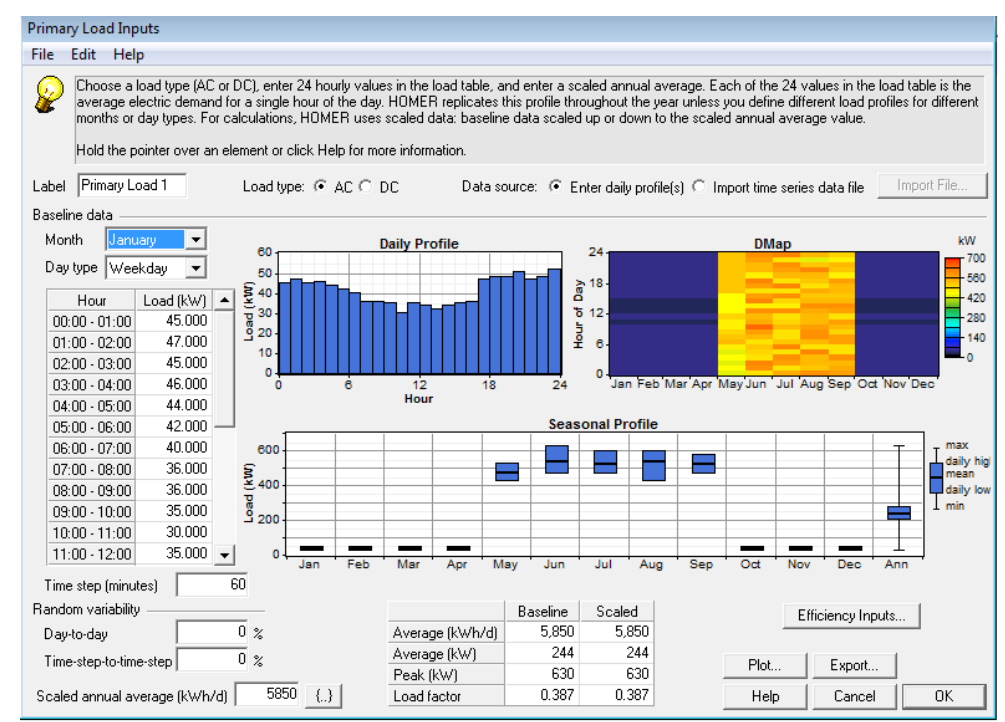

Gambar 3.4 Perancangan Load Bulan Oktober s/d April 2018

Software Homer Energy hanya menggunakan data daya aktif total saja dalam melakukan simulasi daya. Simulasi beban listrik yang digunakan di dalam sistem pembangkit ini diasumsikan random variability $0 \%$ dan time to step $0 \%$ sesuai ketentuan yang dipakai

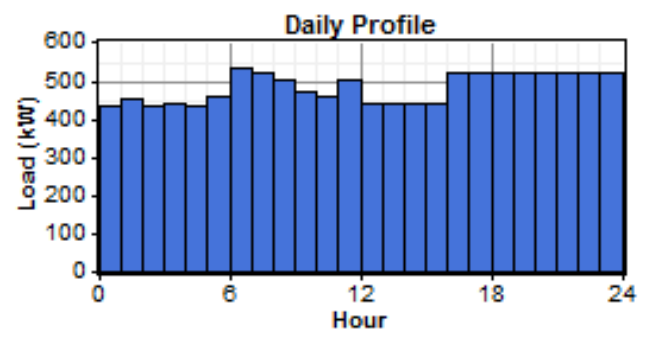

Gambar 3.5 Grafik Penggunaan Energi Listrik Setiap Jam

pada Bulan Mei Sampai dengan September Tahun 2018 


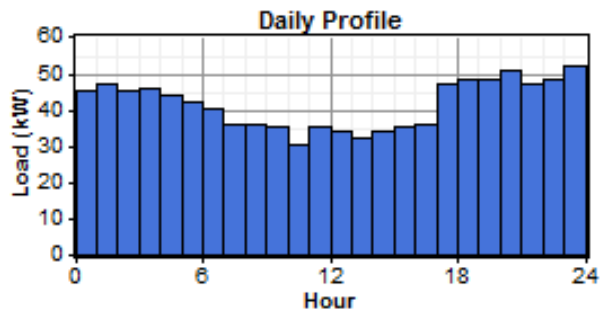

Gambar 3.6 Grafik Penggunaan Energi Listrik Setiap Jam

pada Bulan Oktober Sampai dengan April Tahun 2018

Pada gambar 3.5 menunjukkan grafik penggunaan energi listrik setiap jam selama pabrik sedang berproduksi. Sehingga pada bulan Mei sampai September beban industri diasumsikan sebesar 481,565 kW. Sedangkan gambar 3.6 merupakan grafik penggunaan energi listrik setiap jam selama tidak proses penggilingan atau pabrik tidak produksi berproduksi diasumsikan beban rata-rata adalah 41,375 $\mathrm{kWh}$.

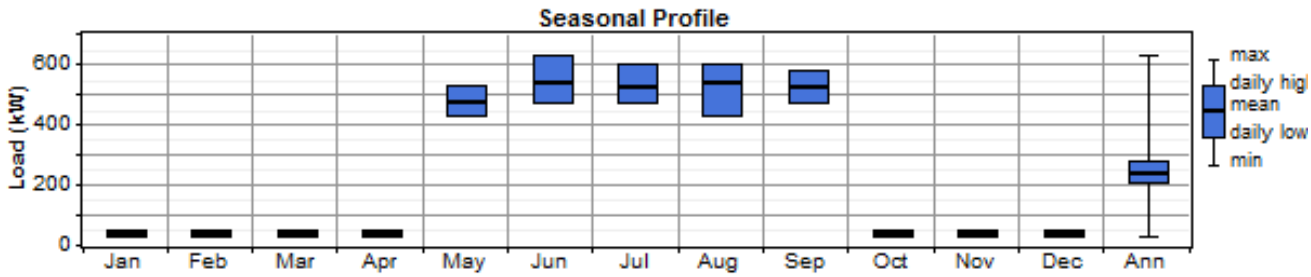

Gambar 3.7 Grafik Profil Daya Listrik Setiap Bulan Selama Setahun

Pada gambar 3.7 menunjukan grafik profil daya pada selama setahun pada saat musim giling maupun tidak dalam produksi atau tidak dalam musim giling.

\section{b. Hasil Daya Generator}

Daya yang dihasilkan generator biomassa $2.000 \mathrm{~kW}$ adalah $2.135,2 \mathrm{kWh} /$ Tahun dengan penggunaan beban produksi perusahaan sebesar 2.416,6 kWh/Tahun. Sedangkan pembelian daya dari PLN sebesar 210,5 $\mathrm{kWh}$ Tahun. Hasil tersebut didapat dari pengolahan data menggunakan software Homer Energy yang ditunjukkan pada gambar 3.8 berikut.

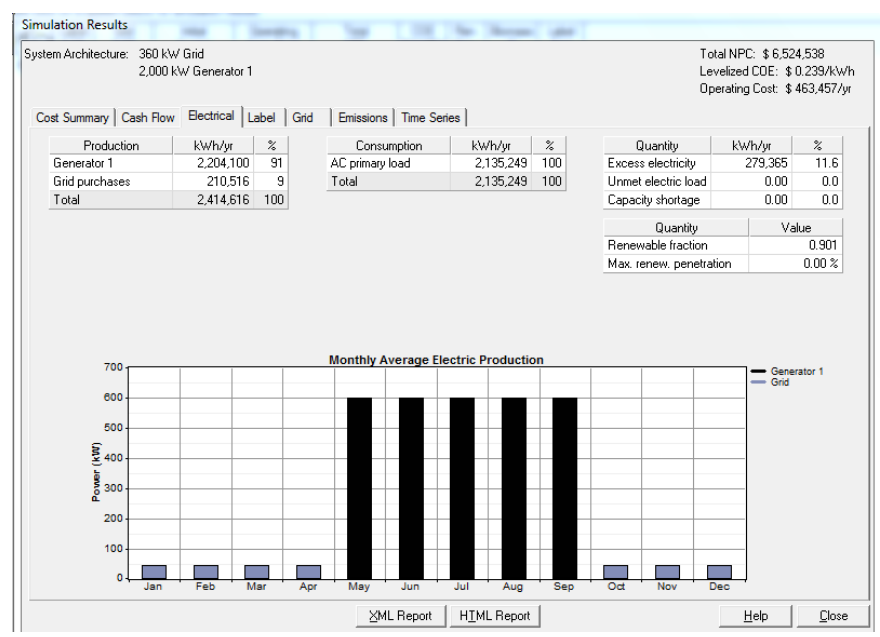

Gambar 3.8 Data Daya yang dihasilkan Generator Biomassa

Halaman Web JRRE : http://jurnalnasional.ump.ac.id/index.php/JRRE 
Software Homer Energy tidak membutuhkan sampling beban setiap menit, tetapi hanya membutuhkan data beban setiap jamnya saja. Data beban diperoleh dari catatan yang ada di Pabrik Gula Sragi, data tersebut selanjutnya di masukkan pada software Homer.

c. Hasil Pembangkit Generator Biomassa

Hasil pembangkit sistem ini berdasarkan dari komponen generator yang sudah terpasang pada Software Homer Energy.

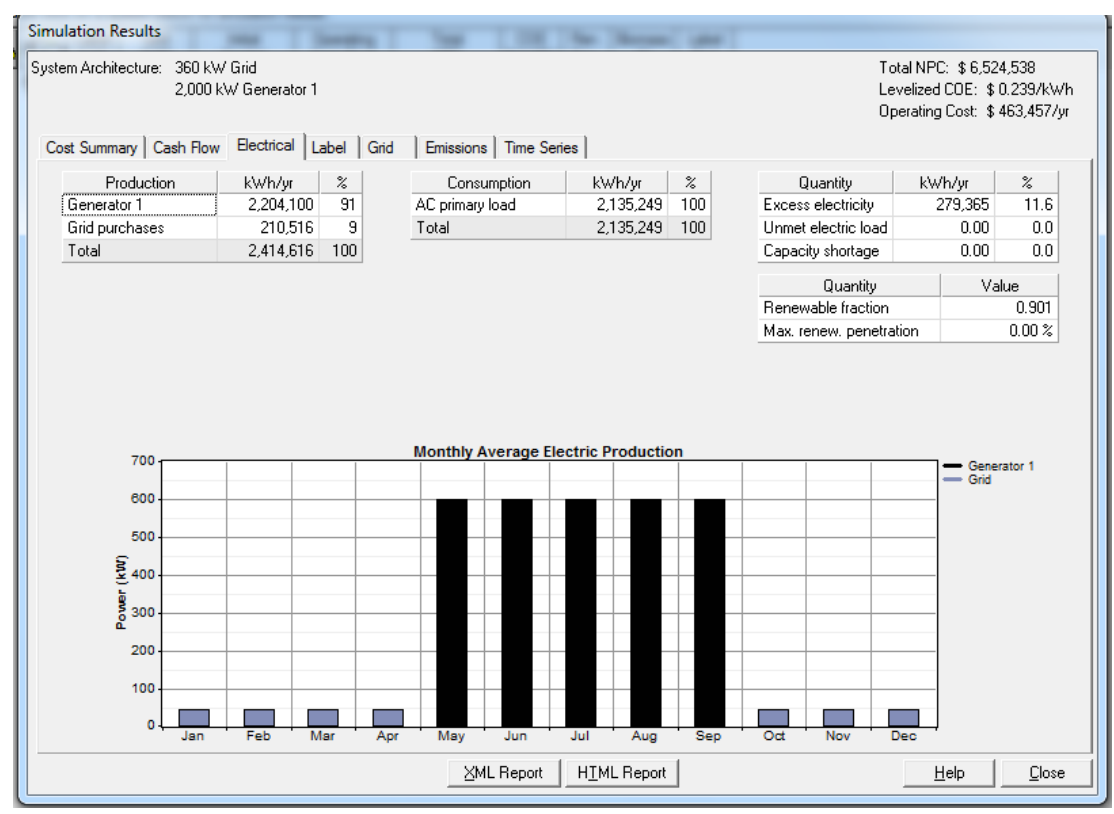

Gambar 3.9 Daya yang dihasilkan dari Konfigurasi Generator Biomassa

Pada gambar 3.9 tampak bahwa total daya yang dihasilkan pembangkit sebesar $2.134,2 \mathrm{kWh} / \mathrm{tahun}$. Dengan konsumsi energi listrik industri sebesar 2.134,2 kWh/tahun (100\%).

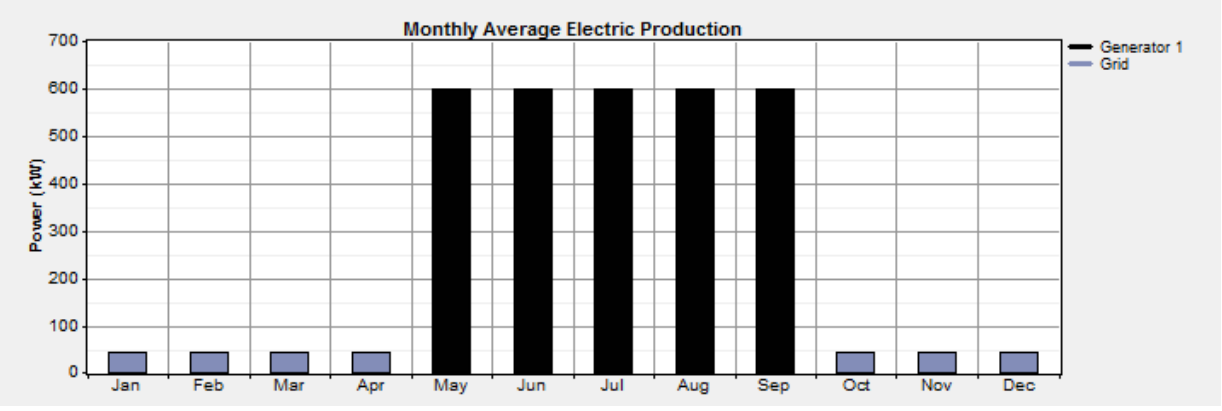

Gambar 3.10 Produksi Listrik per bulan dari hasil Konfigurasi Generator Biomassa Kondisi Optimal

Bagan yang di tunjukkan pada gambar 4.10 menjelaskan bahwa dalam setahun produksi listrik hanya pada bulan Mei sampai September. Karena pada bulan tersebut Pabrik Gula Sragi sedang proses penggilingan dan berproduksi. Sedangkan pada bulan Oktober sampai April Pabrik Gula Sragi tidak berproduksi sehingga suplai daya berasal dari PLN. Dalam hal ini perbandingan antara perhitungan secara teori mendapat selisih yang cukup signifikan karena pada perhitungan secara teori daya energy yang 
terkandung ampas tebu rata-rata dalam 1 tahun sebesar 3.169,92 MW/Tahun namun pada aplikasi Software Homer Energy rata rata dalam 1 tahun sebesar 2.135,2 kW/Tahun. Ampas Tebu yang terhitung secara perhitung teori sebesar 7.469.28 Ton/Tahun namun untuk secara simulasi menggunakan Software Homer Energy ternilai sebesar 5,754 Ton/Tahun Dalam kenyataannya generator yang terpasang pada parik gula memiliki daya sebesar 2 MW dari data yang saya dapatkan di PG. Sragi Pekalongan rata rata dalam 1 hari generator mengahasilkan daya $520 \mathrm{kWh} / \mathrm{Jam}$. Dari perbandingan yang telah dilakukan dapat dianalisis dengan melalui tabel di bawah ini untuk memudahkan analisis.

Tabel 3.2 Perbandingan Analisis Keseluruhan

\begin{tabular}{cccc}
\hline Keterangan & $\begin{array}{c}\text { Perhitungan } \\
\text { Secara Teori }\end{array}$ & $\begin{array}{c}\text { Observasi } \\
\text { Lapangan }\end{array}$ & $\begin{array}{c}\text { Hasil Simulasi } \\
\text { Aplikasi }\end{array}$ \\
\hline $\begin{array}{c}\text { Tebu Giling } \\
\text { (Ton/Tahun) }\end{array}$ & 228.150 & 228.150 & - \\
$\begin{array}{c}\text { Ampas Tebu } \\
\text { (Ton/Tahun) }\end{array}$ & $7.469,28$ & $7.469,28$ & 5.754 \\
$\begin{array}{c}\text { Energi yang } \\
\text { dihasilkan } \\
\text { (MW/Tahun) } \\
\text { Operasi } \\
\text { (Jam) }\end{array}$ & 59.710 & 1.201 & $2.135,2$ \\
$\begin{array}{c}\text { Generator } \\
\text { (MW) }\end{array}$ & 3.672 & 1.959 & 3.762 \\
& 2 & 2 & 2 \\
\hline
\end{tabular}

Berdasarkan tabel 3.2 di atas dapat dianalisis perhitungan yang didapatkan berdasarkan teori dan observasi lapangan berbeda jauh dikarenakan proses konversi energi listrik yang dihasilkan dari ampas tebu dalam observasi lapangan data ampas tebu diambil rata-rata perjam. Pada hasil simulasi software homer energy dan observasi lapangan mendapat selisih energi listrik yang dihasilkan berbeda $1 \mathrm{MW}$ dikarenakan pada software homer energy nilai dari biomassa untuk generator dan jadwal jam kerja generator tidak dapat diubah atau kata lain sudah ditentukan oleh software homer energy.

\section{KESIMPULAN}

Kesimpulan dari hasil penelitian di Pabrik Gula Sragi Pekalongan adalah sebagai berikut :

a. Potensi biomassa limbah ampas tebu sudah dapat memenuhi kebutuhan energi listrik di Pabrik Gula Sragi Pekalongan dengan konsumsi feedstock biomass atau bahan mentah sebesar 68.445,12 ton/ tahun.

b. Konsumsi energi listrik di PG. Sragi Pekalongan pada musim giling sebesar 481,5 kW perjam dan pada saat PG. Sragi Pekalongan tidak musim energy listrik sebesar 41,3 kW perjam.

c. Hasil dari ampas tebu PG. Sragi Pekalongan setelah melakukan perhitungan mendapatkan daya energi listrik sebesar 30,48 MW per jam.

d. Proses mendapatkan ampas tebu dari bahan tebu untuk menjadi ampas tebu (bagasse) yaitu sebesar 27$30 \%$ dari tebu giling. Limbah ampas tebu ini dimanfaatkan oleh PG. Sragi Pekalongan untuk pembakaran boiler karena ampas tebu ini mengandung cukup banyak energi yaitu 1825 kkal untuk proses sebagai pembangkit listrik biomassa.

Halaman Web JRRE : http://jurnalnasional.ump.ac.id/index.php/JRRE 


\section{DAFTAR PUSTAKA}

[1] Baktiman, Slamaet. Volume 1 No. 1, (2012). Optimasi Pembangkit ListrikTenaga Biomasa Sawit Dan Diesel Generator Di Pt. Astra Agro Lestari Menggunakan Software Homer. Teknik Elektro-FTI, Institut Teknologi Sepuluh Nopember (ITS).

[2] E. Toklu. (2017). Biomass energy potential and utilization in Turkey. Department of Mechanical Engineering, Duzce University, Duzce,Turkey.

[3] Kadir, Abdul. 2005. Energi:Sumber daya, Inovasi, Tenaga Listrik, dan Potensi Ekonomi. Jakarta : UI-Press.

[4] Kim, H. J. \& Eom, Y. G. (2009). Thermogravimetric Analysis of Rice Husk Flour for A New Raw Material of Lignocellulosic Fiber- Thermoplastic Polymer Composites. Journal of the Korean Wood Science and Technology, Mokchae Konghak, 37(3), 59-67.

[5] Nusrat Chowdhury, Chowdhury Akram Hossain, Michela Longo \& Wahiba Yaïci (2018). Optimization of Solar Energy System for the Electric Vehicle at University Campus in Dhaka, Bangladesh. Natural Resources Canada, 1 Haanel Drive, Ottawa, On K1a 1m1, Canada.

[6] Sarasuk, K., Sajjakulnukit, B., (2011). Design of a Lab-Scale Two-Stage Rice Husk Gasifier, Journal of 9th EcoEnergy and Materials Science and Engineering Symposium.

[7] Sherrif, F. dan Ross, M., 2003, Validation of PV Toolbox Against Monitored Data and Other Simulation Tools. Hybridinfo 6:2, Varennes: Canada.

[8] Sinta Rahmania, Tiyas. Tugas Akhir (2017). Studi Potensi Ampas Tebu Sebagai Pembangkit Listrik Biomassa di PG Pangka. Program Studi Teknik Elektro Fakultas Teknik Universitas Muhammadiyah Yogyakarta.

[9] Susanto, A. (2008). Pengaruh Tingkat Pembebanan terhadap Distribusi Suhu Gasifikasi Limbah Padat Sekam Padi Menggunakan Updraft Gasifier. Yogyakarta: Jurusan Teknik Pertanian, Fakultas Teknologi Pertanian Universitas Gadjah Mada

Halaman Web JRRE : http://jurnalnasional.ump.ac.id/index.php/JRRE 